\title{
Defending Environmental Rights: an Ecological Democracy Perspective
}

Siti Aliyuna Pratisti and Satriya Wibawa

Department of International Relation, Padjadjaran University

\begin{abstract}
Environmental problems are amongst the most complex issues faced by the Indonesian government. The reason why such problems are difficult to tackle is because environmental protection is often contradictory to the country's development agenda. The case can be viewed as an instance of government misconduct and the neglect of basic environmental rights. Environmental rights themselves are commonly understood as a reformulation and expansion of existing human rights and societal obligations, which an emphasis on environmental protection. However, although environmental rights have received much attention at the grass root level by activist groups, and by everyday members of the community, environmental rights are still not widely recognize at domestic or international levels. Therefore, this research attempts to increaserecognition of environmental rights by proposing the adoption of an ecological democracy perspective, and takes a particular interest in public participation in environmental policy making. Public participation is vital to fostering an ecological democracy, and can be viewed as the key to sustainable development and the defense of environmental rights. The concept of an ecological democracy tries to bridge the gap between the need of the government and those of the public - to ensure that the public can participate freely by providing feedback and decentralized solutions. There are three main types of environmental rights - procedural, substantive, and solidarity rights. As for this research, we will focus primarily on solidarity rights in order to explain public engagement in environmental policy making in Indonesia.
\end{abstract}

Keyword: environmental rights, ecological democracy, community based solidarity

\section{INTRODUCTION}

There are many environmental problems which have arisen in recent years, especially since the beginning of the 20th century when discoveries and scientific advancements ironically turned out to be major threats to human development itself. For example, pollution from motor vehicle fumescauses significant environmental damage, and hazardous waste from heavy industry, and soil erosion from large-scale farming have devastated ecological systems and diminished biodiversity. These examples and others instances of ongoing environmental damage greatly affect the continued survival of human life in the future. Unfortunately, the recognition of these environmental issues within the international community only began in the late 1960s. Furthermore, environmental issues are gaining considerable attention only when their impacts are 
clearly visible ${ }^{1}$. This emerging global concern has led to the development of two pillars, if you will, of implementing environmentalist practices: ${ }^{2}$

1. The need for a political space which allows the community to play a significant role in the policy making process concerning environmental issues, and

2. The inclusion of environmental protection policies during the formation of civil society.

Unfortunately, all over the world there has been significant hindrance in the creation of political spaces where communities and citizens can participate in solving environmental issues. In many cases, the increase in environmental awareness has clashed with the interests of industry and the owners of capital. In Indonesia alone, such cases are countless in number, ranging from government granting of logging permits, land conversion from plantations to industrial sites, and the general exploitation of natural resources. A particularly pertinent example relates to the cement plant operating in Gunung Kendeng, Rembang, Central Java. The community who live in the area of Gunung Kendeng sued the owner of the cement plants and attempted to stop the operation of the plant as it is considered to be the cause of severe environmental damage. On October 14, 2010, the local government permit the construction of a cement plant by issuing a Decision of the Regent Number 545/68/2010 concerning the Mining Business License. On October 6, 2016, the villagers filed a lawsuit to the Supreme Court and granted, so that the plants are forced to closed its operation. But despite the court order, the plant reopened in April 2017 after receiving a green light in the form of act 660.1/30 2016 issued by the Government of Central Java. To this day, the community of Gunung Kendeng has continued voice their dissatisfaction in an effort to maintain the right to access and protect land in Gunung Kendeng.

The Kendeng case illustrates that the process of national environmental policy making, especially in Indonesia, still overlooks the basic environmental concerns of smaller communities. The recognition and protection of environmental rights arevital, especially for agrarian society. Therefore, a country like Indonesia, where $40 \%$ of the population are farmers, environmental rights are tied to the human right to create a living for oneself. Even more, for indigenous peoples, environmental rights are closely related to the free practices of beliefs - for example, the Baduy community(indigenous community of Kanekes) possess a belief system in which theenvironment and nature form the core of their society and culture. Therefore, given the scale to which the environment plays a role in the everyday lives of the Indonesian people, the government should provide greater recognition of the population's environmental rights by involving communities in the policy-making process. It is undeniable that during this process, people's environmental rights often conflict with the industrial interests. However, by adhering to a model of sustainable development, it is hoped that industrial development can go hand in hand with many aspects of environmental protection and environmental rights of local communities. In an effort to raise awareness and increase the recognition of environmental rights, the concept of ecological democracy should beat the heart of policy making and implementation. This will ensure that awareness for environmental principles is raised not only among government officials, but in private industry and the wider society as a whole.

1 Baylis, J. \& Smith, S, The Globalization of World Politics, ( New York: University Press, 2001) p. 387.

2 Hayness, J, Demokrasi dan Masyarakat Sipil di Dunia Ketiga: Gerakan Politik Baru Kaum Terpinggir, (Jakarta: Yayasan Obor Indonesia, 2000) p. 164. 


\section{DEFENDING ENVIRONMENTAL RIGHTS}

It is generally considered that the first environmental case to be discussed in the political sphere was the issue of the collective management of natural resources between Germany France, Austria, Netherlands, Switzerland, and the Czech Republic on the Rhine and the Danube rivers. The Commission of Rhine ratified in 1815 and Commissions of the Danube River ratified in 1856, produced the first treaties based on environmental norms and arranged the manner by which both rivers could be used from an economic perspective. Similarly, the International Treaty of Flora (1954) and the establishment of the International Maritime Organization are considered to have help establish the early norms for international environmental regulations ${ }^{3}$. Formal recognition of an international environmental agenda was first took place in 1972, with the first Environmental Conference in Stockholm, also known as the United Nations Conference on the Human Environment (UNCHE). This conference was attended by 113 countries $^{4}$, and the aim of the conference was to establish an international framework that would promote interstate coordination in seeking solutions to the pollution and other environmental problems. The Stockholm conference produced 26 environmental principles and 109 recommendations on natural resource management ${ }^{5}$.

After 1972, environmental awareness among the international community became increasingly prominent, especially after the nuclear disaster in Chernobyl in 1986, the Valdez oil spill in 1989, and the discovery of holes in the ozone layer over the Antarctic in the mid-1980s ${ }^{6}$. This lead to the establishment of more advanced environmental agreements, such as the Long Range Transboundary Air Pollution Agreement (1979) which regulated air pollution emissions in many European and North American countries, the Vienna Convention of 1985 on the protection of the ozone layer by limiting the use of CFGs, and the Montreal Protocol in 1987. In addition to these environmental regulations, an increase in environmental research began to change the understanding of the environment itself. This shift in perception can be seen through the enactment of the World Charter for Nature in 1982, considered the first agreement to put forward the concept of peoples "environmental rights." This Agreement provided recognition of environmental rights as an integral part of the human rights regime ${ }^{7}$. Due to this initial recognition, the World Charter for Nature has become the primary reference for international legal documents relating to environmental rights. Further support for environmental rights came in the form of the UN Sub-Commission's report on the Prevention of Discrimination and Protection of Minoritiesin 1990. This report outlined the protection of minority rights and the people's right to unhindered access to their environment. The precedents laid out by this report are important since many minority communities still directly rely on their natural environment for their livelihood, and, therefore, they often become victims of the unhindered development and exploitation.

\footnotetext{
Baylis and Smith, supra note 1, p. 389.

White, Brian, Richard Little \& Michael Smith (ed), Issues in World Politics, (New York: St. Martin Press, 1997), p. 164.

Baylis and Smith, supra note 1, p. 390-391.

White, 1997, supra note 4, p. 224.

Atapattu, S., "The Right To A Healthy Life or The Right To Die Polluted?: The Emergence Of A Human Right To A Healthy Environment Under International Law" (2002), Tulane Environmental Law Journal, p. 75.
} 
From the point of view of the Indonesian government, the protection and recognition of environmental rights is included in the constitution, and covered by government regulation, such as Law 32 (2009) on environmental management, and Law No. 39 (2009) on human rights. Based on Article 5 Paragraph (1) of the Indonesian Law 32 (2009): "Everyone has equal rights over good and healthy environment". Furthermore, in addition to possessing said right, according to Article 6 Paragraph (1) of the Environmental Constitution: "Everyone is obliged to preserve the function of the environment and prevent and overcome environmental pollution and destruction". Similarly, Law No. 39 (1999) on Human Rightsreaffirms in Article 9 paragraph (3) that: "Everyone has the right to a good and healthy environment". These ideas are also present within Article $28 \mathrm{H}$, Paragraph 1, of the 1945 Constitution of the Republic of Indonesia, which states: "Everyone has the right to live a prosperous and spiritual life, to live, and to get a good and healthy environment and be entitled to health services". Thelegal bases espoused by the national government are part of an effort to protect the rights of the environment and ensure the sustainability of human life ${ }^{8}$. The human need for a clean and healthy environment, as mentioned above, can be interpreted as making up the core of the concept of environmental rights, and the driving force behind the need for humans to develop harmoniously with their environment. The existence of such guarantees makes it possible (at least legally) for every individual to demand that the rights of the environment be recognized and respected.

Referring to regulations, environmental rights are often defined as an extension of human rights, particularly pertaining to those human wants and actions which are directly related to their environments. There are three forms of environmental rights: procedural rights, substantive rights, and solidarity rights. The first, procedural rights, refers to the right to promote transparency, to participate, and to be accountable for the implementation of environmental policies. In practice, procedural rights include: ${ }^{9}$

1. Freedom of association,

2. The right to gain access to information concerning the environment

3. The right to participate in the process of creating the environment

4. The right to seek environmental justice

The second form in environmental rights, substantive rights, are those rights which are related to protection of the environment under international law. These provide the legal basis for the fulfillment of environmental rights as a component of the right to live in a healthy environmental and the right to have a decent life ${ }^{10}$. In application, the guarantee of these substantive human rights ensures the fulfillment of the related environmental rights. However, the creation and of laws is not always sufficient to guarantee the protection of the environmental rights of communities, therefore it is necessary to raise public awareness concerning people's rights and their obligations toward the environment. This public awareness is related to the aforementioned solidarity rights.

Environmental solidarity refers to community participation and action in solving environmental issues. Currently, there has been only a semblance of environmental

8 Erwin, Muhammad, Hukum Lingkungan dalam Sistem Kebijakan Pembangunan Lingkungan Hidup, (Bandung: Refika Aditama, 2008), p. 10-12.

9 Bruch, C., et al, "Breathing Life into Fundamental Principles: Implementing Constitutional Environmental Protections in Africa", in Ribot, J. C. and Veit, P. G., Environmental Governance in Africa, Working Paper Series, (Washington D.C., USA: World Resources Institute, 2002), p. 135

10 Atapattu, S., supra note 7, p. 96. 
solidarity in Indonesia, and national level, as a means to align with global environmental agendas. In many cases, this global solidarity, so to speak, has taken the form of international networks between communities all seeking to protect similar environmental rights. The Seatle Protest (1999) is most notable example of global movement against capitalism and environmental degradation. This solidarity voiced by activist from various countries based their values on the fulfillment of environmental rights. In some developed countries there are already environmentally conscious political parties, such as the Green Party in Germany. Environmental solidarity takes many forms, from local community's organizations to national political parties, and has made a significant impact in political policy-making ${ }^{11}$.

However, despite the regulation of environmental rights in the international legal level, the implementation of these statues and laws is still far from perfect. The United States' withdrawal from various environmental conventions in early 2017 indicates that the country is reluctant to fulfill obligations concerning environmental rights. Additionally, low levels of environmental education has resulted in a population which is almost oblivious to the many environmental issues. Since public awareness is a major component of creating an ecological democracy and solidarity among grassroots movements, this lack of education is perhaps the main challenge in the effort to achieve environmental rights protection. There is an effort within the environmentalist community to emphasize the importance of securing and enforcing environmental rights. Although it is still far from being realized, a widespread understanding of ecological democracy and community based sustainability will lead to greater protection of environmental rights, especially for the vulnerable communities directly affected by unsustainable development.

\section{Ecological Democracy}

The concept of ecological democracy is based on principles which often underlie environmental justice, environmental policy and democratic principles which involve community participation in environmental policy-making. These principles are rarely applied due to frequent errors in the policy-making framework which leave neglected concerns over environmental sustainability. The principles which comprise the theory of an ecological democracy are applied through environmental protection measures at the local, national or international levels. These principles are based on a strong desire to develop environmental sustainability, increase human responsibility in consuming and using nature resource, and to prevent industry from adversely impacting the environment ${ }^{12}$.

Another study on ecological democracies, described by Nga Dao in his article, Participation: a critical concept in development ${ }^{13}$, emphasizes the importance of community participation in environmental policy making. Nga Dao's article is the result of a case study on the construction of dams and hydropower plants in Vietnam. According to Nga Dao, community participation was a component of the policy-making stage, but in the process of the dam and plant construction the Vietnamese government failed to

11 White, 1997, supra note 4, p. 227.

12 Githinji, P.K., Dressing Political Democracy with Ethics, (2006)., SIEMENPUU Discussion papers, p. 6-11.

13 Nga, D, Participation - A Critical Concept in Development. (2006), SIEMENPUU Discussion papers: 19. 
involve the community. By neglecting democratic principles, there have been prolonged negative impacts for the communities involved. The land that the government selected for dam construction was originally agricultural/residential land, therefore people have been displaced, and there has been a drastic decline in crop production, which has led to famine and starvation. Therefore, it can be seen that the impact of this mismanagement has not only been environmental but also socioeconomic. Consequently, increasingenvironmental awareness encourages people to participate more in environmental policy-making. Similarly, the development an assimilation of green politic in public policy promotes the emergence of "civic environmentalism," or a system where by citizens are heavily invested and environmental protection and developing proactive solutions to environmental issues ${ }^{14}$. These two principles are important components of ecological democracy, and as Nga Daoexplains, community participation is key in the effort to preserve the environment because the community is the lead actor in environmental conservation ${ }^{15}$.

The inclusion of democratic principle in dealing with environmental issues is necessary because within existing power networks (i.e. government and private companies), which often require people to accept environmental policies which are inconsistent with their own desires and needs. Worse, local communities are often the party which is primarily effected by as environmental devastation Therefore, the development of ecological democracy is the key to creating community participation in sustainable development without neglecting the public interest (Isomaki, 1991). Ecological democracy will arise when citizens can freely engage in the environmental policy-making processes, or show a strong desire to participate by providing ideas and solutions to local environmental issues. Ecological democracy is an alternative model of democracy that focuses on the following: ${ }^{16}$

1. Encourage government to give more attention to environmental policy, so that environmental issues can be addressed systematically,

2. Raise awareness and engage local communities in the creation of environmental policy. ${ }^{17}$

In keeping with Mitchel's findings, the effectiveness of environmental conservation efforts, according to Haynes ${ }^{18}$ is dependent on existing political conditions. Efforts to preserve the environment work well in democratic countries where a strong civil society has already been established. However, in a democratic country with an underdeveloped civil society, efforts at environmental conservation will encounter many obstacles. Mitchel mentions various factors that keep an ecological democracy from being realized. First, the powerful influence of the global capitalist economy which often drives industrial development with littleregard for the potential environmental impact. Second, the existence of closed democratic government systems often leads to political entrapment. Third, the absence of rights equality, or obligatory recognition of rights pertaining to the environment. Fourth, technological innovation has not prioritized environmental sustainability. And fifth, the absence of mediation and communication

14 Shutkin, W. A., The Land that Could Be: Environmentalism and Democracy in the Twenty-first Century, (Cambridge, MA: MIT Press, 2000).

15 Nga D, supra note 13, p. 23.

16 Mitchell, R.E. "Green politics or environmental blues? Analyzing Ecological Democracy" (2006), 15: 459-480, Public Understanding of Science.

17 Mitchel, supra note 16, p 470.

18 Hayness, supra note 2, p. 167. 
between local communities and the government. Mitchel also outlines factors that facilitate the formation of an ecological democracy ${ }^{19}$ :

1. Strong sense of social and government responsibility towards the environment.

2. An open democratic model which can act as a channel for society to address environmental issues.

3. The prompt perception and detection of threats to the environmental.

4. The support of local culture towards the growth of ecological democratic principles.

5. The expansion of local or global environmentalist networks which promote ecological democratic principles.

Concerning the study environmentalism and the fulfillment of environmental rights, a thorough understanding of green politics and the principles of ecological democracy is needed to establish a clear framework for environmental policy making.

\section{Engaging People: Community Based Solidarity}

The modern environmental law in Indonesia was born since the enactment of Law No. 4 (1982) on the Basic Provisions of Environmental Management, dated March 11, 1982. Later, the Law 4 (1982) replaced by Law 23 (1997) which was then renewed through Law 32 (2009). The renewal of environmental law in Indonesia is in line with global environmental laws that are also emerging after the first Conference on the Human Environment was held in Stockholm, in June 1972. Along with it, solidarity movement that initially promoted environmental issues began with the emergence of international non-state organizations (INGO). Furthermore, it also outlined significant changes which have occurred in the study of international politics; issues outside the scope of state security concerns, such as economics and the environment, are afforded more attention by the pluralist perspective. This change in perspective also changes the manner by which grassroots movements interact with the government and other organizations and actors. NGOs which originally operated only on a national basis have begun to spread globally with and operate as part of a worldwide network.

On the global scale, the environmental movement can be viewed as a cooperative collection of "green" parties from various countries which promote global environmental regulations such as the Kyoto Protocol, etc. Additionally, there are also non-state international organizations, such as Greenpeace (established in 1971), Environmental Defense Fund (established in 1967), or Friends of the Earth International (established in 1969), which are at the forefront of efforts to prevent environmental damage. The environmentalist movement aims to increase global awareness of environmental issues, but has no one consolidated system of beliefs. For example, though the movement generally encourages governments to construct effective and appropriate environmental regulations, there are some organizations, such as the Indian Center for Service and Environment (CSE) for example, which take their efforts as far as rejecting globalization as a whole in reference to pluralism within environmentalism, the state alone is not the sole actor, but works in tandem with non-state organizations and local communities in order to develop environmental policy.

As mentioned above, non-governmental organizations have become one of the most influential actors in the defense of environmental rights. One of the most wellknown and active non-governmental organizations in Indonesia is The Indonesian

19 Mitchel, supra note 16, p. 478. 
Forum for the Environment (WALHI) established in 1980. Currently, WALHI has spread to 28 provinces in Indonesia, and has amassed a membership of 479 members, with an increase of 156 members in 2017. The organization also campaigns internationally through Friends of the Earth, an international NGO with at least 71 branches in 70 countries, 15 affiliated organizations, and more than 2 million individual members. WALHI's ultimate goal is to oversee Indonesia's ecological development by promoting sustainable solutions to environmental problems and upholding social justice. With the goal of realizing "a just and democratic social, economic and political order that can secure people's rights to healthy living and environmental resources", WALHI has attempted to become an independent and professional leader in environment-focused advocacy. WALHI also functions as mechanism watchdog for state policies and regarding ecological issues.

In addition to NGOs, many individual initiatives have led to a greater defense of environmental rights in Indonesia. A number of individuals have even been labeled as environmental heroes by the Indonesian government for their work to promote and protect environmental rights. Their actions have inspired a greater degree of solidarity among the people of areas impacted by environmental damage. However, despite the increase in environmental awareness, unfortunate events have transpired which have led to the repression, or worse, of these individual defenders of environmental rights. As case in point, Salim Kancil, an environmental activist working to defend the rights of farmers in Lumajang, was killed while in has struggle against rampant sand mining operations near his village. It is evident that environmental defenders face many threats, including that of both mental and physical violence. Another restrictive measure is the criminalization of acts undertaken by individual environmental defenders. Despite the fact that Article 66 of Law No. 32 of 2009 on Environmental Protection and Management states that environmental defenders can't be criminalized by civil or criminal law, in the reality, this protection is rarely invoked.

On the other hand, there have been some environmental activists fortunate enough to obtain awards and significant recognition for their work. Some of their success stories have become famous both in Indonesia and in the international community. Wellknown names include: Prigi Arisandi, Yuyun Ismawati, Yosepha Alomang and Botor Dingit. All of the aforementioned individuals have received theGoldman Environment Award in different years. Prigi Arisandi is known for attempting to improve water quality in Surabaya. His efforts were inspired by the belief that the quality of local rivers and waterways negatively effects the quality of the city's drinking water, as the Surabaya River is the source from which PDAM Surabaya provides drinking water to the residents of Surabaya. He also worked to warn the local industries of the dangers inherent in disposing waste into the river, and also had vocally reprimanded the Governor of East Java for his negligence in protecting the environment.

Another activist, Yuyun Ismawati, designed a water supply system for both rural and urban areas in Bali. He then decided to help the poor by designing an efficient waste management facility which placed a priority on ensuring environmental health and continued economic benefits for local people. Yet another standout activist, Mama Yosepha (Yosepha Alomang) who became a prominent female figure in Amungme, Papua, due to her struggle against PT Freeport Indonesia. In 1991, Yosepha held a three-day demonstration at the airport in Timika, which included lighting a fire on the airstrip. She was protesting both PT Freeport's and the Indonesian government's refusal to allow the people of Papua to voice their concern over the devastation of their environmental devastation. Unfortunately, to this day the struggle against PT Freeport 
continues. In late 2003, when a mining pit collapsed in Freeport's Grasberg mine and killed nine miners, Yosepha again called for the closing of all of PT Freeport's operations in Indonesia. Her activism was influential in helping to create broader understanding of environmental rights and solidarity concerning environmental problems.

Botor Dingit, another well-known activist, managed to unite and organize the Dayak Indigenous Communities in 1993. He formed and served as the chairman of an activist group called Sempekat Jato Rempangan (SJR). He and SJR worked to achieve recognition for the environmental rights of the Bentian people. He is regarded as a hero for managing to keep the ancestral lands of the Bentian from the hands of irresponsible capitalist ventures, and, in so doing, ensuring that the environment remained sustainable and undamaged.

In addition to the global ecological movement and individual activism, local solidarity also plays a significant role in helping shape and enforce environmental protection. A recent example of such solidarity was displayed by the Mount Kendeng community in Rembang, Central Java, when they opposed the construction of a cement plant which was projected to cause severe damage to the surrounding environment. Residents of the Mount Kendeng community held peaceful demonstrations in front of the State Palace in order to voice their concern about damage to their community and environment. Although their efforts are ongoing and as of yet have not produced the desired results (the cement plant has been re-opened) the community has demonstrated that grassroots solidarity movements have the potential to help raise the alarm over environmental problems.

Another case where a form of ecological democracy based on grassroots solidarity was undertaken in a rural fishing community in Cambodia. The people of Chong Knie, in Siem Reap, were tired of the violence, intimidation tactics, and corruption perpetrated by the local government and large ship owners operating in the waters near their community. Led by one Ning Savat, a veteran of the Cambodian Civil War, The community held protests against various shipping/fishing policies which were detrimental to the local environment. However, many of these protests were met with violence perpetrated by local authorities ${ }^{20}$. However, although this movement, like that in Mount Kendeng Rembang, has not achieved its ultimate aim (the local government continues to protect and large industry), it has succeeded in broadening national awareness concerning the environment and spurred the Cambodian government to start to develop laws which are more in line with the principle of sustainable development.

As shown in the examples above, community participation is an important pillar in the creation of an ecological democracy. This is in line with John Rawls's view ${ }^{21}$ that the most important thing to consider during policy-making is the public's wishes, wants, and desires. Political institutions must maintain mechanisms by which the voices of the public can influence policy making. Concerning environmental conservation in particular, a policy-making must also reflect ideas of environmental rights. When a person lives alone, he still obliged to not to damage the environment. In order to relate this idea to the practice of ethical government and environmental policy, one can

20 Ratner, Blake, "Environmental Rights As A Matter Of Survival" (2004), 2:11, Human Rights Dialogue, p. 6.

21 Humprey, Matthew, "Ecological Politics and Democratic Theory: The Challenge to the Deliberative Ideal", (London: Routledge, 2008), p. 115. 
consider the words of Immanuel Kant, who argued that a moral political community consists of capable and responsible individual ${ }^{22}$.

In reference to Kant, Dobson ${ }^{23}$ argues that, in conjunction with environmentalism, there also exists the concept of ecologism, or the desire to change the human relationship with nature and introduce social and political system which are less anthropocentric. While environmentalism is concerned more with the managerial approach in addressing environmental issues, ecologism tries to develop radical much more comprehensive level of environmental awareness ${ }^{24}$. Ecologism offers a more nuanced view of environmental devastation: damage to the environment is not solely the result of the inappropriate use of technology or development strategies but rather result of a misstep in the relationship between the biotic (living) and the abiotic (natural) communities. Additionally, ecologism proffers a model for improving human living conditions, as opposed to merely solving environmental issues. The principles of ecologism can provide a direction for local communities in an effort to realize deeper environmental sustainability. From the above examples, it can be seen that the people of Gunung Kendeng and fishermen in Chong Knie have adopted ecological principles. The environmental awareness they display is also in keeping with their socio-cultural values, thereby enabling a greater degree of community participation in solving environmental issues, and laying the groundwork for the implementation of an ecological democracy.

\section{CONGLUSION}

Environmental rights can be defined as a subset of human rights which focus on the fulfillment and recognition of those rights and obligations related to access to a clean and functioning environment. Efforts to ensure environmental rights have been carried out at the international, regional, and national levels through the adoption and internalization of a number of environmental treaties and laws. However, in practice, there are still many violations of environmental rights due to conflicts of interests between various societal groups, some of whom profit from the continued exploitation of natural resources. Therefore, to further strengthen the protection and respect for environmental rights, local community participation in environmental policy making is necessary. The movement to increase this community participation parallels the international solidarity movement, which is already strengthening the protection of environmental rights on a broader scale. Environmental solidarity within Indonesian society, as demonstrated by the efforts of the people of Gunung Kendeng, also showed by the fishermen in Chong Knie, Cambodia, demonstrates a willingness to participate in grassroots environmentalism.

Public participation is also vital in guaranteeing the fulfillment of environmental rights at the national and international levels. Only by close observation of the policy making processcan we begin to establish an ecological democracy which can effectively mediate the interactions between the government and the public. Based on data analysis, important conclusions can be drawn regarding a model for the creation of an ecological democracy. First, public participation and engagement in an ecological

22 Burns, Tony, "What is Politics? Robinson Crusoe, Deep Ecology and Immanuel Kant", Politics vol. 2, no. 2, (Oxford: Blackwell Publisher, 2002), p 96.

23 Dobson, Andrew, Green Political Thought, 4th ed., (New York: Routledge, 2007), p. 2.

24 Ibid, p. 3. 
democracy can be undertaken by various elements of society, including environmental NGOs, environmental observers and local community organizations. The means by which these groups can voice their ideas and opinions also varies, and includes demonstrations, lawsuits, discussion forums, and participation and membership in political parties. Second, public participation in environmental issues is the benchmark by which one can assess the degree to which the public is aware of environmental issues. Moreover, the ecological democratic model of open political systems provides space for the communities to channel their aspirations and to create awareness concerning potential environmental threats. Similarly, support from social and cultural entities, and from local and global networks, such as worldwide forum held by Grassroots Global Justice Alliance, can contribute to the formation of an ecological democracy.

Lastly, a necessary component of the construction of an ecological democracy, and, by proxy, guarantee of environmental rights, is a change in the mentality of the general public concerning the environment. In particular, perhaps what is needed is a dissemination of the mindset already adopted by both local and global environmentalist networks. While these networks already provide a powerful impetus for increased concern for the environment within local communities by introducing them to information on environmental issues. Through this transfer of information and knowledge, hopefully these communities can become independent agents of environmental conservation, and can help provide the national government with solutions to future environmental problems. With the support of an independent society and an open government, and ideal ecological democracy can be realized.

\section{BIBLIOGRAPHY}

Atapattu, S., "The Right To A Healthy Life or The Right To Die Polluted?: The Emergence Of A Human Right To A Healthy Environment Under International Law" (2002), Tulane Environmental Law Journal.

Baylis, John \& Steve Smith, The Globalization of World Politics, (New York: University Press, 2001).

Bruch, C., "Breathing Life into Fundamental Principles: Implementing Constitutional Environmental Protections in Africa", in Ribot, J. C. and Veit, P. G., Environmental Governance in Africa, Working Paper Series, (Washington D.C., USA: World Resources Institute, 2002).

Burns, Tony, "What is Politics? Robinson Crusoe, Deep Ecology and Immanuel Kant", Politics vol. 2, no. 2, (Oxford: Blackwell Publisher, 2002).

Dobson, Andrew, Green Political Thought, 4th ed., (New York: Routledge, 2007).

Erwin, Muhammad, Hukum Lingkungan dalam Sistem Kebijakan Pembangunan Lingkungan Hidup, (Bandung: Refika Aditama, 2008).

Githinji, P.K., Dressing Political Democracy with Ethics, (2006), SIEMENPUU Discussion papers, p. 6-11.

Hayness, J, Demokrasi dan Masyarakat Sipil di Dunia Ketiga: Gerakan Politik Baru Kaum Terpinggir, (Jakarta: Yayasan Obor Indonesia, 2000).

Humprey, Matthew, Ecological Politics and Democratic Theory: The Challenge to the Deliberative Ideal, (London: Routledge, 2008).

Mitchell, R.E. "Green politics or environmental blues? Analyzing Ecological Democracy" (2006), 15: 459-480, Public Understanding of Science. 
Siti Aliyuna Pratisti and Satriya Wibawa

Nga, D, Participation - A Critical Concept in Development. (2006), SIEMENPUU Discussion papers, p. 19-25.

Ratner, Blake, "Environmental Rights As A Matter Of Survival" (2004), 2:11, Human Rights Dialogue, p. 6-7.

Shutkin, W. A., The Land that Could Be: Environmentalism and Democracy in the Twenty-first Century, (Cambridge, MA: MIT Press, 2000).

Viotti, Paul \& Mark Kauppi, International Relations Theory: Realism, Pluralism, Globalism, (London: Macmillan Pub., 1993).

White, Brian, Richard Little \& Michael Smith (ed), Issues in World Politics, (New York: St. Martin Press, 1997).

Siti Aliyuna Pratisti, is a lecturer at the Department of International Relation, Faculty of Social and Political Science. In 2013, Aliyuna started antimateri.com, a selfpublished webzine that she and her colleagues develop as an alternative public sphere.

Satriya Wibawa, is a lecturer at the Department of International Relations Universitas Padjadjaran, Bandung, West Java, Indonesia. He is concerned on human security and environmental issues in Indonesia. 